\title{
KAJIAN PENANGANAN TERHADAP ANAK BERKEBUTUHAN KHUSUS
}

\author{
${ }^{(1)}$ Purba Bagus Sunarya, ${ }^{(2)}$ Muchamad. Irvan dan ${ }^{(3)}$ Dian Puspa Dewi ${ }^{(2)}$ \\ (1) Mahasiswa, ${ }^{(2,3)}$ Dosen Pogram Studi Pendidikan Khusus FKIP Universitas PGRI Adi Buana Surabaya \\ Email: purbasunarya@gmail.com ${ }^{(1)}$,Mch.Irvan@gmailcom ${ }^{(2)}$,Dianpuspadewi90@gmail.com ${ }^{(3)}$
}

\begin{abstract}
ABSTRAK
Anak-anak dengan kebutuhan khusus adalah anak-anak cacat atau hambatan fisik, mental, intelektual, sosial, atau emosional, seperti: anak-anak dengan autisme, tuli, buta, retradasi mental, cacat fisik dan lain-lain dapat memiliki pengaruh yang signifikan terhadap proses pertumbuhan atau perkembangan dibandingkan dengan anak-anak lain seusianya. Jika kondisi ini tidak ditangani dengan baik, perkembangan kemampuan anak mengalami kendala dan beban orang tua, keluarga, masyarakat dan negara. Tujuan penanganan yang dilakukan oleh semua ahli akan berdampak positif bagi anak-anak dengan kebutuhan khusus. Dalam berbagai aspek seperti di bidang akademik mampu mengikuti pelajaran dengan baik, di bidang sosial anak-anak mampu bersosialisasi dengan masyarakat dan di bidang emosi anak dapat menyalurkan emosi menjadi hal-hal positif. Orang tua atau keluarga sebagai penyedia layanan utama untuk anak-anak dengan kebutuhan khusus, pada umumnya masih kurang memiliki kesadaran dan tanggung jawab untuk memberikan hak dan kesempatan yang sama bagi anak-anak. Ini karena kurangnya pengetahuan orang tua atau keluarga tentang cara merawat, mendidik, memelihara dan memenuhi kebutuhan anak-anak ini. Orangtua atau keluarga adalah faktor yang paling penting dalam memfasilitasi pertumbuhan dan perlindungan anak-anak dengan kebutuhan khusus.
\end{abstract}

Kata Kunci: Anak Berkebutuhan Khusus, Layanan

\begin{abstract}
Children with special needs are children with disabilities or physical, mental, intellectual, social, or emotional barriers, such as: children with autism, deaf, blind, mental retradation, physical disability and others can have a significant effect on the process of growth or development compared to other children of his age. The problem of children with special needs is a problem that is quite complex in quantity and quality. This condition if not handled properly, the development of the child's ability to experience obstacles and the burden of parents, family, community and country.The purpose of handling done by all experts will have a positive impact for children with special needs. In various aspects such as in the field of academics able to follow the subjects well, in the social field of children able to socialize with the community and in the field of emotion children can channel emotions into positive things. Parents or families as primary service providers to children with special needs, generally still lack the awareness and responsibility to provide equal rights and opportunities for the children. This is because the lack of knowledge of parents or families about how to care for, educate, nurture and meet the needs of these children. Parents or families are the most important factor in facilitating the growth and protection of children with special needs
\end{abstract}

Keyword: Children with Special Needs, Services 


\section{PENDAHULUAN}

Anak berkebutuhan khusus adalah anak yang mengalami keterbatasan atau hambatan, baik fisik, mental-intelektual, sosial, maupun emosional, seperti : anakautis, tunarungu, tunanetra, tunagrahita, tunalaras, tunadaksadan lain-lain dapat berpengaruh secara signifikan dalam proses pertumbuhan atau perkembangannya dibandingkan dengan anak-anak lain yang seusia dengannya. Masalah anak berkebutuhan khusus merupakan masalah yang cukup kompleks secara kuantitas maupun kualitas. Mengingat berbagai jenis anak berkebutuhan khusus mempunyai permasalahan yang berbedabeda, maka dibutuhkan penanganan secara khusus. Jika anak berkebutuhan khusus mendapatkan pelayanan yang tepat, khususnya keterampilan hidup (life skill) sesuai minat dan potensinya, maka anak akan lebih mandiri. Namun, jika tidak ditangani secara tepat, maka perkembangan kemampuan anak mengalami hambatan dan menjadi beban orangtua, keluarga, masyarakat dan negara.

Pihak yang menangani identifikasi merupakan pihak professional di bidangnya masing-masing.Kegiatan identifikasi sifatnya masih sederhana dan tujuannya lebih ditekankan pada menemukan atau mengenali apakah seorang anak tergolong anak dengan kebutuhan khusus atau bukan. Maka biasanya identifikasi dapat dilakukan oleh orang-orang yang dekat (sering berhubungan/bergaul) dengan anak, seperti orang tua, guru, dan pihak-pihak yang terkait dengannya. Sedangkan langkah berikutnya, yang sering disebut asesmen, bila diperlukan dapat dilakukan oleh tenaga profesional, seperti dokter, psikolog, neurolog, orthopedagog, therapis, dan lain-lain.

Tujuan penangananyang dilakukan oleh semua ahli akan berdampak positif bagi anak berkebutuhan khusus.Dalam berbagai aspek seperti dalam bidang akademik mampu mengikuti mata pelajaran denganbaik, dalam bidang social anak mampu bersosialisasi dengan masyarakat dan dalam bidang emosi anak dapat menyalurkan emosi kedalam hal yang positif. Orangtua atau keluarga sebagai pemberi layanan utama terhadap anak berkebutuhan khusus, pada umumnya masih kurang mempunyai kesadaran dan tanggung jawab untuk memberikan persamaan hak dan kesempatan bagi anakanak tersebut. Hal ini dikarenakan kurangnya pengetahuan orangtua atau keluarga tentang bagaimana merawat, mendidik, mengasuh dan memenuhi kebutuhan anak-anak tersebut. Orangtua atau keluarga merupakan faktor terpenting dalam memfasilitasi tumbuh kembang dan perlindungan anak berkebutuhan khusus.

\section{METODE PELAKSANAAN}

Pelaksanaan kegiatan pengabdian kepada masyarakat oleh dosen program studi Pendidikan Khusus FKIP Unipa Surabaya dengan tema Keterlibatan Orang Tua dalam Kegiatan Pemberian Layanan Pendidikan Bagi Anak Berkebutuhan Khusus dilaksanakan dalam 2 hari yaitu:

a) Hari I pada tanggal 26 Maret 2018

Pada pelaksanaan hari pertama diberikan oleh Muchamad Irvan, S.Pd., M.Pd dengan materi sebagai berikut: 1) Pemberdayaan Masyarakat dalam pelayanan pendidikan bagi anak berkebutuhan khusus, dijelaskan apa saja peran masyarakat dalam pelayanan anak berkebutuhan khusus, dan 2) Sikap masyarakat terhadap anak berkebutuhan khusus, dijelaskan bagaimana sikap seseorang sebagai bagian dari masyarakat dalam memberikan hak pada anak berkebutuhan khusus

b)Hari II pada tanggan 30 Maret 2018. Pada pelaksanan hari kedua ini materi diberikan oleh Dian Psupa Dewi, S.Pd.,M.Pd dengan materi Pihak-pihak yang terkait dalam pemberian layanan pendidikan bagi anak berkebutuhan khusus, dijelaskan unsur-unsur masyarakata dalam pemenuhan pelayanan pendidikan bagi anak bekrebutuhan khusus.

\section{HASIL DAN PEMBAHASAN}

\section{A. Anak Berkebutuhan Khusus}

1. Pengertian anak berkebutuhan khusus Dalam buku Exceptional Children and Youth, menurut William Cruickshank dan G. Orville Jonhson 
(1958 : 3), pengertian anak berkelainan: pada dasarnya anak berkelainan adalah seseorang anak yang mengalami penyimpangan intelektual, phisik, sosial atau emosional secara menyolok dari apa yang dianggap sebagai pertumbuhan dan perkembangan normal, tentu saja yang bersangkutan tidak dapat menerima manfaat maksimal dari program sekolah umum dan memerlukan kelas khusus atau tambahan pengajaran dan berbagai layanan.

2. Klasifikasi anak berkebutuhan khusus

a. Tunarungu

Menurut Somad dan Hernawati (1996 : 27), mengemukakan bahwa pengertian tunarungu adalah Seseorang yang mengalami kekurangan atau kehilangan kemampuan

mendengar baik sebagian atau seluruhnya yang diakibatkan karena tidak berfungsinya sebagian atau seluruh alat pendengaran, sehingga ia tidak dapat menggunakan alat pendengarannya dalam kehidupan sehari - sehari yang membawa dampak terhadap kehidupannya secara kompleks.

Anak tunarungu diklasifikasikan menjadi; (a) Ketunarunguan ringan, yaitu kondisi di mana orang masih dapat mendengar bunyidengan intensitas 20-40 dB (decibel, disingkat $\mathrm{dB}$, ukuran untuk intensitas/tekananpada bunyi). Mereka sering tidak menyadari bahwa sedang diajak bicara,mengalami sedikit kesulitan dalam percakapan. (b) Ketunarunguan sedang, yaitu kondisi di mana orang masih dapat mendengar bunyidengan intensitas 40-65 dB. Mereka mengalami kesulitan dalam percakapan tanpamemperhatikan wajah pembicara, sulit mendengar dari kejauhan atau dalamsuasana gaduh, tetapi dapat terbantu dengan alat bantu dengar (hearing aid). (c) Ketunarunguan berat, yaitu kondisi di mana orang hanya dapat mendengar bunyidengan intensitas 65-95 dB. Mereka sedikit memahami percakapan pembicara bila memperhatikan wajah pembicara dengan suara keras, tetapi percakapan normal praktis tidak mungkin dilakukannya, tetapi dapat terbantu dengan alat bantu dengar.

(d) Ketunarunguan parah, yaitu kondisi di mana orang hanya dapat mendengar bunyi dengan intensitas $95 \mathrm{~dB}$ atau lebih keras. Percakapan normal tidak mungkin baginya, ada yang dapat terbantu dengan alat bantu dengar tertentu, sangat bergantung pada komunikasi visual

Selain itu anak tunarungu memiliki karakteristik sebagai berikut; Karakteristik dalam segi Intelegensi : anak tunarungu akan mempunyai prestasi lebih rendah jika dibandingkan dengan anak normal pendengarannya untuk materi yang diverbalisasikan. tetapi untuk materi yang tidak diverbalisasikan prestasi anak tunarungu akan seimbang dengan anak mendengar. Karakteristik dalam Segi Bahasa dan Bicara: karena anak tunarungu tidak bisa mendengar, kemampuan berbahasanya tidak akan berkembang bila tidak dididik atau dilatih secara khusus. akibat dan ketidakmampuannya di bandingkan dengan anak yang mendengar dengan usia yang sama, maka dalam perkembangannya akan jauh tertinggal. Karakteristik Dalam Segi Emosi dan Sosial: egosentrisme yang melebihi anak 
normal, mempunyai perasaan, ketergantungan terhadap orang lain, perhatian mereka lebih sukar dialihkan (Somad Permanaria, 1995:36-39)

b. Tunanetra

1) Pengertian tunanetra

Somantri (2006 : 65), Tunanetra adalah Individu yang indra penglihatannya

(kedua-duanya) tidak berfungsi sebagai saluran penerima informasi dalam kegiatan sehari-hari sepertihalnya orang awas. Anak Tunanetra memiliki keterbatasan atau bahkan ketidak mampuan dalam menerima rangsang atau informasi dari luar darinya melalui indra penglihatannya. Penerimaan rangsang hanya dapat dilakukan melalui pemanfaatan indra-indra lain diluar indra penglihatan.

2) Klasifikasi tunanetra

a) Buta : Dikatakan buta bila anak sama sekali tidak mampu menrima rangsang cahaya dari luar (visusnya -0)

b) Low Vision : Bila anak masih mampu menerima cahaya dari luar, tetapi ketajamannya lebih dari $6 / 21$, atau jika anak hanya mampu membaca headline pada surat kabar

3) Karakteristik tunanetra Keterbatasan dalam memperoleh informasi tertentu dari lingkungan sekitarnya, memiliki kepekaan indera pendengar yang tinggi, pada hal-hal tertentu anak tunanetra masih tergantung pada orang lain, memiliki perasaan yang mudah tersinggung, karena keterbatasan dalam rangsangan visualnya, mempunyai perasaan curiga yang besar pada orang lain, sebagai akibat dari keterbatasan tunanetra dalam melakukan orientasi dengan lingkungan sekitar, rasa keingintahuannya sangat tinggi

c. Tunagrahita

1) Pengertian tunagrahita

Definisi tunagrahita menurut

AAMD

(American

Association of Mental

Deficiency) bahwa

keterbelakangan mental menunjukkan fungsi

intelektual dibawah rata-rata secara jelas dengan disertai ketidakmampuan dalam penyesuaian perilaku dan terjadi pada masa perkembangan (Somantri, 2006: 104).

2) Klasifikasi tunagrahita : mampu didik, mampu rawat dan mampu latih

3) Karakteristik tunagrahita

Keterhambatan fungsi

kecerdasan secara umum atau di bawah ratarata., ketidakmampuan dalam perilaku sosial, hambatan perilaku adaptif terjadi pada usia perkembangan yaitu sampai dengan usia 18 tahun.

d. Tunadaksa

1) Pengertian tunadaksa Tunadaksa dapat dikatakan pula sebagai cacat tubuh. White House Conference (1931) mengemukakan bahwa, tunadaksa berarti suatu keadaan rusak atau terganggu sebagai akibat gangguan bentuk atau hambatan pada tulang, otot, dan sendi dalam fungsinya yang normal. Kondisi ini dapat disebabkan oleh 
penyakit, kecelakaan, atau dapat juga disebabkan olah pembawaan sejak lahir (Somantri, 2006: 121).

2) Klasifikasi tunadaksa anak tunadaksa yang mengalami kelainan ortopedi (poliomyelitis, muscle dystrophy, spina bifida, dll); anak tunadaksa yang mengalami kelainan saraf yaitu cerebral palsy (spastic, dyskenisia, ataxia, dll).

3) Karakteristik tunadaksa

a) Anggota gerak tubuh kaku/lemah/lumpuh,

b) Kesulitan dalam gerakan (tidak sempurna,tidak lentur, tidak terkendali),

c) Terdapat bagian anggota gerak yang tidak lengkap/tidak sempurna/lebih kecil dari biasa

e. Tunalaras

1) Pengertian tunalaras

"Anak tunalaras adalah anak yang mengalami hambatan emosi dan tingkah laku sehingga kurang dapat atau mengalami kesulitan dalam menyesuaikan diri dengan baik terhadap lingkungannya dan hal ini akan mengganggu situasi belajarnya" (Somantri. 2006: 140)

2) Klasifikasi tunalaras

Anak tunalaras dapat diklasifikasikan kedalam beberapa jenis. menjadi dua, yaitu: anak tunalaras dengan tingkah laku yang beresiko tinggi dan anak tunalaras dengan tingkah laku yang beresiko rendah. Anak tunalaras dengan tingkah laku yang beresiko tinggi antara lain: hiperaktif, agresif, pembangkang, anak yang menarik diri dari lingkungan. Sedangkan anak tunalaras dengan tingkah laku yang beresiko rendah antara lain: autism dan scizofrenia

3) Karakteristik tunalaras

a) Bersikap membangkang,

b) Mudah terangsang emosinya/ emosional/ mudah marah,

c) Sering melakukan tindakan agresif, merusak, mengganggu,

d) Sering bertindak melanggar norma sosial/ norma susila/ hukum

f. Autis

1) Pengertian autis

Anak autis adalah anak yang mengalami dan memiliki karakteristik gangguan dalam komunikasi sosial dan interaksi sosial yang disertai dengan prilaku berlebihan, minat terbatas serta memiliki gangguan dalam hubungan timbal balik sosial (Arlington, 2013 : 207) Pada umumnya, anak-anak autism spectrum disorder menunjukan karakteristiknya yaitu kesulitan bersosialisasi dengan teman sebaya atau orang lain dilingkungan sekitarnya, tidak mampu merespon suatu aktivitas yang sedang berlangsung disekitarnya. (Kaufman, 2013 : 57).

2) Klasifikasi autis

a) Level 3 "Membutuhkan dukungan yang sangat besar"Defisit parah dalam keterampilan komunikasi sosial verbal dan nonverbal menyebabkan gangguan parah pada fungsi, inisiasi yang sangat terbatas interaksi 
sosial, dan respon minimal terhadap tawaran sosial dari orang lain. Misalnya, dengan

beberapa kata dari bahasanya tidak dimengerti, jarang memulai interaksi.

b) Level 2 "Membutuhkan dukungan substansial"

Defisit dalam keterampilan komunikasi sosial verbal dan nonverbal, gangguan sosial, inisiasi terbatas interaksi sosial, dan mengurangi atau menanggapi yang abnormal atau tidak sesuai terhadap tawaran sosial dari orang lain. Level 1 "Membutuhkan dukungan"

Tanpa adanya dukungan dari lingkungan, defisit dalam komunikasi sosial pada anak autis menyebabkan gangguan interaksi sosial. Kesulitan memulai interaksi sosial, dan contoh-contoh yang jelas dari respon atipikal atau gagal terhadap tawaran sosial lain.

3) Karakteristik autis

a) Komunikasi sosial : Kesulitan dalam penggunaan komunikasi sosial baik verbal dan nonverbal seperti berikut defisit mengakibatkan keterbatasan fungsional dalam komunikasi yang efektif, partisipasi sosial, hubungan sosial, prestasi akademik, atau kinerja kerja, secara individu atau dalam kombinasi.

b) Interaksi sosial : Defisit dalam perilaku komunikatif nonverbal digunakan untuk interaksi sosial misalnya dari komunikasi verbal dan nonverbal buruk, kelainan pada kontak mata dan bahasa tubuh atau defisit dalam pemahaman dan penggunaan gerakan, kurangnya ekspresi wajah dan komunikasi nonverbal.

c) Perilaku : Gerakan motorik stereotipe atau berulang, penggunaan benda, atau bahasa (misalnya, stereotypies gerakan tubuh, berbaris mainan atau membalik benda, echolalia).

g. Anak berkesulitan belajar

1) Pengertian anak berkesulitan belajar

Hallahan dan Kauffman dalam Delphie (2006: 24) mengemukakan bahwa:

Kesulitan belajar spesifik yang terjadi berkaitan dengan faktor psikologis sehingga mengganggu kelancaran berbahasa, saat berbicara, dan menulis, pada umumnya mereka tidak mampu menjadi pendengar yang baik, untuk berpikir, untuk berbicara, membaca dan menulis, mengeja huruf, bahkan perhitungan yang bersifat matematika. Kondisi kelainan dapat disebabkan oleh perceptual handicaps,brain injury, minimal brain dysfunction, dyslexia, and developmental aphasia.

2) Klasifikasi anak berkesulitan belajar Kirk dan Gallagher dalam Wardani, Hernawati, dkk (2007: 8.5) menjelaskan bahwa kesulitan belajar dibedakan dalam 2 kategori besar yaitu:

a) Kesulitan belajar yang berhubungan dengan perkembangan (developmental learning disabilities)
b) Kesulitan belajar akademik (academic learning disabilities)


3) Karakteristik tunagrahita

a) Aspek kognitif

Masalah-masalah kemampuan bicara, membaca, menulis, mendengarkan, berpikir, dan matematis semuanya merupakan penekanan terhadap aspek akademik atau kognitif.

b) Aspek bahasa Masalah bahasa anak berkesulitan belajar menyangkut bahasa reseptif maupun ekspresif.

c) Aspek motorik

Masalah motorik anak berkesulitan belajar biasanya menyangkut keterampilan motorik-perseptual yang diperlukan untuk mengembangkan keterampilan meniru pola.

d) Aspek sosial dan emosi

Terdapat dua karakteristik sosialemosional anak berkesulitan belajar ialah: kelabilan emosional dan keimpulsif-an. Kelabilan emosional ditunjukakan oleh sering berubahnya suasana hati dan temperamen. Tingkat impulsive merujuk kepada lemahnya pengendalian terhadap dorongandorongan untuk berbuat seseuatu

\section{h. Anak berbakat}

1) Pengertian anak berbakat

Anak berbakat atau anak yang memiliki kemampuan dan kecerdasan luar biasa adalah "anak yang memiliki potensi kecerdasan (intelegensi), kreativitas, dan tanggungjawab terhadap tugas(task commitment) di atas anak-anak seusianya (anak normal), sehingga untuk mewujudkan potensi nya menjadi prestasi nyata, memerlukan Pendidikan khusus" (Direktorat Pendidikan Luar Biasa 2004:22).

2) Klasifikasi anak berbakat

Linguistik, Logis-matematis, Spatial, Musikal, Jasmani kinestetik, Interpersonal, dan Intrapersonal.

3) Karakteristik anak berbakat Punya kepercayaan diri yang kuat, Konsisten dengan keinginannya sampai terpenuhi, Peka terhadap situasi di sekelilingnya, Senang dengan hal-hal yang baru, Senang bergaul dengan anak-anak yang lebih tua.

\section{B. Pihak Yang Terlibat}

1. Orang Tua

Ayah dan/atau ibu seorang anak, baik melalui hubungan biologis maupun sosial. Umumnya, orang tua memiliki peranan yang sangat penting dalam membesarkan anak

2. Guru

Seorang pengajar suatu ilmu. Dalam bahasa Indonesia, guru umumnya merujuk pendidik profesional dengan tugas utama mendidik, mengajar, membimbing, mengarahkan, melatih, menilai, dan mengevaluasi peserta didik

3. Dokter

Orang yang memiliki kewenangan dan izin sebagaimana mestinya untuk melakukan pelayanan kesehatan, khususnya memeriksa dan mengobati penyakit dan dilakukan menurut hukum dalam pelayanan kesehatan

4. Psikiater

Profesi dokter spesialistik yang memiliki spesialisasi dalam diagnosis dan penanganan gangguan

emosional. Psikiater tidak hanya menangani masalah gangguan jiwa berat, tetapi juga ringan

5. Konselor

Seorang yang mempunyai keahlian dalam melakukan konseling/penyuluhan

6. Ahli terapifisik(fisioterapist) Seseorang yang mempunyai ilmu yang menitikberatkan untuk menstabilkan atau memperbaiki gangguan fungsi alat gerak/fungsi tubuh yang terganggu yang kemudian diikuti dengan proses/metode terapi gerak 
7. Ahli Terapi kognitif (cognitive behavioral terapist)

Seorang ahli yang menangani masalah klinik seperti cemas, schizophrenic, substance abuse, gangguan kepribadian, gangguan mood. Dalam prakteknya, terapi ini dapat diaplikasikan dalam pendidikan, tempat kerja dan seting lainnya.

8. AhliTerapiperilaku(behavioral terapist)

Seorang yang memberikansalah satu terapi kepada Anak Berkebutuhan Khusus dimana terapi ini difokuskan kepada kemampuan anak untuk merespon terhadap lingkungan dan mengajarkan anak perilakuperilaku yang umum

9. AhliTerapiokupasi(occupational terapist)

Seorang yang memberikan layanan kesehatan kepada masyarakat atau pasien yang mengalami gangguan fisik dan atau mental dengan menggunakan latihan/aktivitas mengerjakan sasaran yang terseleksi(okupasi) untuk meningkatkan kemandirian individu pada area aktivitas kehidupan sehari-hari, produktivitas dan pemanfaatan waktu luang dalam rangka meningkatkan derajat kesehatan masyarakat

10. Ahli Terapi wicara

Seorang yang mempunyaisuatu ilmu/kiat yang mempelajari perilaku komunikasi normal/abnormal yang dipergunakan untuk memberikan terapi pada penderita gangguan perilaku komunikasi, yaitu kelainan kemampuan bahasa, bicara, suara, irama/kelancaran, sehingga penderita mampu berinteraksi dengan lingkungan secara wajar

11. AhliT erapi massage
Seorang yang

memilikikemampuanrelaksasi dengan memberikan tekanantekanan tertentu pada anggota badan. Teknik relaksasi adalah teknik untuk menurunkan respon relaksasi sebagai mekanisme protektif terhadap stress yang menurunkan, denyut nadi metabolisme, laju pernapasan dan tonus otot

12. Masyarakat

Sekelompok orang yang membentuk sebuah sistem semi tertutup (atau semi terbuka), di mana sebagian besar interaksi adalah antara individu-individu yang berada dalam kelompok tersebut

\section{KESIMPULAN}

Keterlibatan

pihak- pihak professional bagi anak berkebutuhan khusus memiliki makna yang berarti bagi proses perlindungan dan tumbuh kembangnya. Oleh karena itu, pengetahuan dan peningkatan kapasitas pendamping, yaitu orangtua, keluarga, dan masyarakat, dalam menghadapi anak berkebutuhan khusus sejak dini akan memberikan dampak signifikan dalam merawat, memelihara, mendidik, dan meramu bakat atau potensi yang dimiliki setiap anak berkebutuhan khusus. Kesiapan dan kesiagaan orang tua dan keluarga yang memiliki anak berkebutuhan khusus merupakan kunci sukses penanganan, ditambah dukungan dari masyarakat dan pemerintah dalam menyediakan lingkungan dan fasilitas yang ramah terhadap anak berkebutuhan khusus.

\section{REFERENSI}

Arlington, V.A. 2013. Diagnostik and Stastitical Manual of Mental Disorder, Fifth Edition (DSM 5). Washington. American Psychiatric Assosiation

Cruickshank, William dan G. Orville Jonhson. (1958) .Exceptional Children and Youth. New Jersey : Prentice-Hall, Inc 
Kauffman, Walter. 2013. Symphosium: The New Diagnostig Criteria for Autism Spectrum Disorder. Departement of Neurology Boston Children's Hospital.Harvard Medical School. Harvard.

Somantri, Sutjihati. 2006. Psikologi Anak Luar Biasa, Bandung: Refika Aditama.

Sunardi dan Sunaryo. 2007. Intervensi Dini Anak Berkebutuhan Khusus. Jakarta : Depdiknas.

Thomas J. Berndt (1997) Parental Socialization of Positive and Negative Emotions: Associations With Children's Everyday Coping and Display Rule Knowledge.

Dissertation. North Carolina University.

Thomas, R. \& Zimmer-Gembeck, M. (2007). Behavioral outcomes of parentchild interaction therapy and Triple $P$ i Positive Parenting Program: A review and meta-analysis. Journal ofAbnormal Child Psychology, 35, pp. $475-495$

Van Ryzin, Mark J dkk. 2016. Family-Based Prevention Programs for Children and Adolescents. New York: Psychology press.

Zepeda, Marlene dkk. 2004. Improving Children's Behaviour and Attendance throughthe Use of Parenting Programmes:An Examination of Good Practice.London: Institute of Education, University of London 